\title{
JURIDICAL ANALYSIS OF TAX PAYABLE REPORT ON E-COMMERCE TRANSACTIONS IN ORDER TO REALIZE LEGAL CERTAINTY
}

\author{
ABDUL RAHMAN TIBAHARY \\ arie_recht@yahoo.com
}

\begin{abstract}
Information technology has a profound influence on the world economy. In relation to extend of these technologies, especially telecommunications, multimedia and information technology (telematics) can eventually change the order of the organization and social relationships. In this study question the fulfillment about statements of the tax payable on the E-Commerce transaction which of course will not be apart from the tax law concerning on the E-Commerce transaction, statements against the tax payable on the E-Commerce transaction and legal certainty in conducting the tax report on the E-commerce transaction.

The method used in this research is descriptive analytic is a research method that aims to describe the facts in the form of the data to the primary legal materials in related to the form of laws and regulations and the secondary legal materials (doctrine, the expert opinion of the leading law) as well as tertiary legal materials. While the approach in this study used a qualitative which seeks to combine normative and empirical. In this research are expected to acquire a comprehensive describe of the tax payable statement on the E-Commerce transaction.

The result on the tax on E-Commerce transactions equal to the ordinary transactions in accordance with the explanation in Article 11 section (1) Law Concerning Income Tax that regulated Value Added Tax and Sales Tax on Luxury Goods adheres to the accrual principle, it meaning the tax occurs in when the delivery of taxable goods or on the delivery of taxable services, although payment for such delivery has not yet fully accepted or received, or in the importation of taxable goods. When the tax payable for transactions made through the ECommerce are subject to this article. The tax payable related to the report which is derived from the transactions on the E-Commerce it can be undertaken with the approach of harmonization and convergence so that certainty of the tax report above electronic transactions can be implement as well as possible.
\end{abstract}

Keyword: E-Commerce, E-Commerce Transaction, Tax Law, Tax Amnesty, Legal Certainty.

\section{INTRODUCTION}


Today's business world can be done either directly or using interconnected computers called the Internet. Because it is supported by an internet network so that business people can sell and offer services online. The Internet is the world's largest computer network currently in use by millions of people spread across the world.

It is marked by the birth of the use of internet as a medium trading company or the consumer in a transaction that causes every individual has the right and ability to relate to other individuals without any restriction. The rapid development in the field of technology in various sectors also has an impact on developments in the business world. It can be seen from the business activities through E-Commerce, as a result of advances in communications and information technology sector. Rapid progress in the business world is not always followed by the same level in the field of regulation. E-commerce is a modern trading methods that do not reconcile between the seller and the buyer, then the occurrence of an agreement is difficult to know exactly when the agreement between the two sides took place.

There are many definitions for E-Commerce, but certainly E-Commerce refers to all forms of commercial transactions involving organizations and individuals that are based on the process and transmission of data digitized, including text, sound and images. Including the effect that the electronic exchange of commercial information that may occur between supporting institutions and commercial activities of the government. These include, among others, organizational management, contract negotiation and commercial, legal and regulatory framework, preparation of financial agreements and tax each other.

Electronic Commerce, as part of the Electronic Business (business conducted using electronic transmission), by experts and business people trying formulated definition. Generally speaking E-Commerce can be defined as any form of trade or commerce of goods and services using electronic media. Obviously, apart from those mentioned above, that the commercial activity is a part of business activities.

In contrast to ordinary trade transactions in general, E-Commerce transactions have some special characteristics that result in rather complicated tax implications of these activities. This happens because electronic transactions between e-merchants (parties that offer goods or services via the internet) with e-customers, (parties that buy goods or services through the internet) that occur in cyberspace or on the internet generally take place in a paperless transaction, while the document used in the transaction is not a paper document, but an electronic document (digital document).

Currently, the tax is the largest contributor to the State Budget which means a main role for continuing development of this nation. Tax are a source of state revenue that is essential for the administration and national development. So the government put tax obligations as a manifestation of a state which is a means of financing the state in national development in order to achieve the purpose of the state.

Related to electronic commerce transactions are taxed according to regulations, business communities that offer electronically to consumers who are in the country of Indonesia shall be subject to the tax regulations in Indonesia because they meet the physical presence and conduct business operations remain in Indonesia.

The Directorate General of Tax issued a Surat Edaran-62/PJ/2013 issued in December 2013 (concerning Affirmation of Tax Terms on E-Commerce Transactions) which is expected to be an affirmation that the tax provisions related to E-Commerce transactions are the same as the provisions starting from registering, calculate, pay, report, it also applies to every business conducting e-Commerce.

RESULT AND DISCUSSION 


\section{LEGISLATION GOVERNIG ABOUT TAX ON E-COMMERCE TRANSACTIONS}

Tax on E-Commerce transactions in accordance with SE-62/PJ/2013 has determined that there are no new taxes in E-Commerce transactions, so there is no difference in the application of tax legislation between E-Commerce transactions or conventional. Therefore, the seller or buyer can be taxed according to existing tax legislation.

Tax on E-Commerce transactions aimed at implementing fairness for all taxpayers of both conventional and E-Commerce. Basically the obligations of conventional business taxpayers or E-Commerce are no different.

Failure to collect taxes from E-Commerce transactions will result in not carrying out the principle of fairness and certainty in law enforcement, resulting in unbalance in competition between employers because of uneven tax burden among the taxpayers, as well as state revenues from taxes that are not optimal.

The result on the tax on E-Commerce transactions equal to the ordinary transactions in accordance with the explanation in Article 11 section (1) Law Concerning Income Tax that regulated Value Added Tax and Sales Tax on Luxury Goods adheres to the accrual principle, it meaning the tax occurs in when the delivery of taxable goods or on the delivery of taxable services, although payment for such delivery has not yet fully accepted or received, or in the importation of taxable goods. When the tax payable for transactions made through the ECommerce are subject to this article.

As explained in the affirmation of tax regulations SE-62/PJ/2013 on E-Commerce, development of information and communication technology has led to the transformation of business models and strategies necessary to emphasize the aspect of Tax. In principle, the transaction of goods and / or services over electronic systems, hereinafter referred to as ECommerce together with the transaction of goods and / or other services, but differ in terms of method or device used. Therefore, there is no difference in tax treatment between transactions E-commerce and transaction of goods and / or other services.

In the Directorate General of Tax Circular is given the task of defining aspects of the General Provisions and Tax Procedures, Income Tax and Value Added Tax and Sales Tax on Luxury Goods E-Commerce transactions.

Subject of Tax will be taxed when receiving or generating an income. The legal basis is the Value Added Tax Legislation Number 7 of 1984 on Value Added Tax (VAT), as amended by Legislation Number 36 of 2008. The legislation regulates Tax to the tax subject related to that obtained in the tax year.

As explained, there are three principles of tax namely Principle of Domicile or Principle of Residence, where the state has the right to impose tax on all income of taxpayers residing in their territory, both income originating from within and outside the country, and this principle applies for domestic taxpayers. The Principle of Source, where the state is entitled to tax on income originating in the territory regardless of the taxpayer's residence. Principle of Nationality, where the Tax linked to the nationality of a country.

Countries of the Organization for Economic Co-operation and Development (OECD) have agreed that the Levies of income tax on E-Commerce transactions that have permanent establishments will use the Principle of Source, if it does not have permanent establishments will use the Principle of Domicile.

Permanent Establishments under Article 2 paragraph (5) of the Income Tax law that permanent establishment is an establishment used by an individual who does not reside in Indonesia, an individual who is in Indonesia for not more than 183 (one hundred and eightythree) days within a period of twelve (12) months, and entities that are not incorporated and 
domiciled in Indonesia for conducting business or conducting activities in Indonesia, which can be, place of management, branch companies, representative offices, office building, factory, workshop, warehouse, space for promotion and sales, mining and natural resource extraction, mining working area of oil and gas, fisheries, animal husbandry, agriculture, farming, or forestry.

Construction, installation or assembly project, Provision of services in any form by employees or others, all made more than 60 (sixty) days within a period of twelve (12) months, person or body to act as an agent whose position does not free, agent or employee of an insurance company not established and not domiciled in Indonesia that receives insurance premiums or carries risks in Indonesia, computers, electronic agents or automated equipment owned, leased or used by providers of electronic transactions to carry out business activities through Internet.

The tax implications for E-Commerce will arise if the tenants for space on an Internet Service Provider or Internet service provider are companies domiciled abroad. That all transactions related to the preparation for operating the website, to a server owned by the taxpayer abroad, their treatment will be the same as those described above. For example, one of the website tenants, who is a foreign taxpayer, uses the website to store certain information, which is then offered to third parties, so that third parties become customers, and those customers pay contributions to access the intended information, will be included in the royalty category in accordance with the explanation of Article 4 paragraph (1) letter (h) of the Income Tax law. So that if the customer is an Indonesian taxpayer, then the website tenant must be deducted by Article 26 Income Tax.

Value Added Tax (VAT) is a tax charged on imported delivery of taxable goods or taxable services by Entrepreneur Taxable, and can be worn many times every value and can be credited. The legal basis is the Value Added Tax Legislation Number 8 of 1983 on Value Added Tax or Sales and Luxury Goods, as amended by Legislation Number 42 of 2009.

As stated in Article 11 (1) of Legislation Number 8 of 1983 as amended in Legislation Number 42 of 2009, the tax payable occurs at the time, Delivery of Taxable Goods, Import of taxable goods, Delivery of Taxable Services, Utilization of taxable goods Intangible Outside Customs Area, utilization of Taxable Services from Outside Customs Area, taxable goods Tangible Export, Export Taxable Intangible Goods, Export Taxable Services.

Value Added Tax according to Article 12 of Legislation Number 42 of 2009 means that the Taxable Person for VAT purposes is taxed at the place of residence or place of business and place of business carried out or other place stipulated by the Directorate General of Tax. Directorate General of Tax can designate one or more places as a place of tax payable. In the case of imports, the tax payable occurs at the place where Taxable Goods are included.

The Levies is carried out by Directorate General of Customs and Excise, individuals or entities utilizing Intangible Taxable Goods and / or Taxable Services originating from outside the Customs area within the Customs area, tax payable at the place of residence or place of residence and / or place of activity business.

This is similar to the Organization for Economic Co-operation and Development (OECD), which recommend the place due from Value Added Tax and Sales Tax on Luxury Goods, where there is consumption of goods / services, in Article 1 of the four models of Tax for transactions E- Commerce namely Tax of cross-border trade must be under the jurisdiction where consumption is carried out.

The principles of Tax on E-Commerce is Neutrality, Tax should be neutral and fair in distinguishing between forms of E-Commerce transactions with the shape of a conventional transaction. Business decisions should be motivated by economic conditions compared to tax 
considerations. Taxpayers in the same situation and the transaction should be subject to the same also in the level of Tax. Efficiency, Compliance costs for Taxpayers and Administrative costs for tax officials should be minimized as far as possible.

Certainty and Simplicity, tax regulations must be clear and easy to understand, so taxpayers can anticipate tax consequences before a transaction occurs, including knowing when, where and how the tax is calculated. Effectiveness and Fairness, Tax must produce the right amount of tax itself, so it must be able to minimize the potential for tax avoidance and tax evasion while still measuring the risks that can occur. Flexibility, Tax systems should be flexible and dynamic to ensure they are in line with technology and commercial development. So there is no right to relieving the E-Commerce from taxes. The amount of tax will be imposed on transactions with electronic media is as much as can be taxed with physical media.

With the existence of these Tax principles, the nature of the enactment of these legal rules is inseparable from the applicable law due to the determination of the ruler of the state, and the law that does not depend on the human view of the good and bad of the original law. That all events in this world are governed and driven by an eternal law which forms the basis of the power of all other regulations.

There are 4 kinds of legal categories (rechtscategorien), the lex aeterna, lex naturalist, lex divina, positive law. Lex Aeterna (Eternal Law), namely the ratio of God Himself which regulates all things that are in accordance with their goals and characteristics, because it is the source of all laws; Lex Divina (Divine Law), which is a small part of God's ratio revealed to humans; Lex Naturalis (Natural Law), which is part of Lex Divina which can be captured by human ratios or is the incarnation of Lex Aeterna in the human ratio; and Positive Law, which is the law that applies in society.

\section{TAX PAYABLE REPORT ON E-COMMERCE TRANSACTIONS IN ORDER TO REALIZE LEGAL CERTAINTY}

Law is a system of norms that emphasize the aspect of "should" or das sollen, to include some rules about what to do. Norms are products and deliberative human actions. Legislation contains rules of a general nature as a guide for the individual to behave in society, both in relationships with other people and in relation to society. These rules become a limitation for the community in overloading or taking action against individuals. The existence of these rules and the implementation of these rules lead to legal certainty.

In addition to legal certainty, tax law also has various functions that are based on principles that aim to improve the welfare of the population. The first function in tax law is as a reference in creating a tax Levies system that must meet the certainty, efficient, and simple requirements as clearly as possible in the tax law, as well as a source that explains about which and who the subject and object need and does not need to be a source of Tax serves to increase the potential for tax in this country. The tax payable report serves as a reference in the distribution of the tax burden to the people based on the interests of each person.

Approaching realistic legal goals is legal certainty. Can be pointed out that the "summum ius summa injuria, summa lex, summa crux" which means harsh laws may hurt, but justice can help him, so although justice is not a legal purpose only but the purpose of the law's most substantive is justice.

According to Article 1 paragraph (10) of Legislation Number 16 of 2009 it is stated that the tax payable is a tax that must be paid at a time, in the Tax Period, in the Tax Year, or in the Tax Year Section in accordance with the provisions of tax laws and regulations. Knowing the determination of the tax payable by a Taxable Entrepreneur in carrying out his 
tax obligation is very important. Without knowing the current tax payable, could not be determined when the Taxable Entrepreneur must meet their tax debt repayment obligations.

Determination of the tax currently payable is closely associated with the onset of the determination of the tax debt. Levy of Value Added Tax and Sales Tax on Luxury Goods adhere to the principle of accrual, meaning the tax occurs upon delivery of the taxable goods or taxable services, although payment for supply is not received or have not fully accepted at the time of import of taxable goods.

When the tax is due for transactions carried out through E-Commerce, it is subject to this provision: Submission of Taxable Goods, Import of Taxable Goods, Delivery of Taxable Services, Utilization of intangible Taxable Goods from outside the Customs Area. In the case of an individual or an entity uses intangibleTaxable from outside the Customs Area within the Customs Area or utilizing Taxable Services outside the Customs Area within the Customs Area, tax payable occurs when an individual or entity begins utilizing Taxable Goods tangible or Taxable Services within the Customs Area.

This is related to the fact that those who provide intangible Taxable Goods or Taxable Services are outside the Customs Area so that they cannot be confirmed as Taxable Entrepreneurs. Therefore, current tax payable is no longer associated with the time of delivery, but at the moment associated with the use, utilization of Taxable Services from outside the Customs Area, intangible Taxable Goods Export, Export intangible Taxable Goods, Export Taxable Services.

In the event that payment is received prior to submission of Taxable Goods or before delivery of Taxable Services or in the case of payments being made before the commencement of utilization of intangible Taxable Goods or Taxable Services from outside the Customs Area, the tax is due at the time of payment.

Tax reporting can be sent to the Tax Service Office or Service Office, Counseling and Tax Consultation where taxpayers are registered. Notification letters can be divided into Period Notification and Annual Notification.

Notice Period is the Notice that is used for reporting on tax payments on certain period (monthly). There are 9 (nine) types of Period Notification Letters, including Period Notification Letters to report monthly payments. Income Tax Article 21, Income Tax Article 22, Income Tax Article 23, Income Tax Article 25, Income Tax Article 26, Income Tax Article 4 paragraph (2), Income Tax Article 15, Value Added Tax and Sales Tax on Luxury Goods, Levies Value-added tax.

While the purpose of the Annual Tax Return is the Notice that is used for annual reporting. There are 2 (two) types of annual tax returns, annual corporate tax returns, and individual taxpayers' annual tax returns.

Currently specifically for the Notification of Value Added Tax Period can be delivered electronically through the e-Filling application. Filing tax return can also be made online through the application of e-SPT. Tax Base are as follows.

Selling price is the value in money, including all costs on request or should be requested by the seller for delivery of taxable goods are not included in the Value Added Tax, which collected according to the Legislation of Value Added Tax and discounts that are set out in the Tax Invoice.

Replacement is the value in money including all costs on request or should be requested by the employer for the delivery of taxable services, export of taxable services, or export of taxable goods Intangible, but not included in the Value Added Tax which collected under the Legislation Value Added Tax and discounts that are set out in the tax Invoice or value of the money to be paid or should be paid by the recipient of services for the utilization 
of taxable services and / or beneficiaries of taxable goods Intangible due to the utilization of taxable goods Intangible from outside the Customs Area within the Customs Area.

Import Value is the value of money which becomes the basis for calculating import duty added based on the provisions in legislation governing customs and excise for the import of Taxable Goods, excluding Value Added Tax and Sales Tax on Luxury Goods collected under the Law Value Added Tax. Export value is the value of money including fees on request or should be requested by the exporter.

Application of Tax Base set in a variety of regulations implementing the law as follows. For delivery or sale of taxable goods, which become the Tax Base is the amount of the selling price. For delivery of the taxable services Tax Base is the replacement. For import the Tax Base is the value of imports. For export the Tax Base is the value of exports.

Tax payment deadline set in Article 21 of the Income Tax In pay off later than 10 (ten) the following calendar month. Report no later than 20 (twenty) next calendar month. Article 22 Income Tax In paying off on the same day with the implementation of payment for supply of goods financed from state budget. Report no later than 14 (fourteen) days after the next calendar month. Article 23/26 Income Tax, Paid at the latest on the 10th (ten) of the following calendar month. Report the latest 20 (twenty) months in the next calendar month. Value Added Tax and Sales Tax on Luxury Goods, Paid at the latest on the 15th (fifteenth) of the following calendar month. Report the latest 20 (twenty) months in the next calendar month.

Delay in Tax Reporting for Notification of Value Added Tax Period subject to a fine of Rp. 500,000.00 (five hundred thousand rupiah) and for other Periodic Notices subject to a fine of Rp. 100,000.00 (one hundred thousand rupiah) and Annual Corporate Income Tax subject to fines amounting to Rp.1,000,000.00 (one million rupiah).

In accordance with the Regulation of the Ministry of Finance Number 80-PMK.03 / 2010 on the Determination of Payment Due Date and Payment of Tax Determination Tax Payments place, and Procedures for Payments, Deposits and Tax Reporting and Procedures In Installments and Tax Payment Delays, set on Tax Payment and Reporting, as follows. Article 2 paragraph (13) Value Added Tax payable on its own building activities must be paid by an individual or entity carrying out its own building activities no later than 15 (fifteen) months after the Tax Period ends.

Article 2 paragraph (13A) Value Added Tax payable on the utilization of intangible Taxable Goods and / or Taxable Services from outside the Customs Area must be deposited by an individual or entity utilizing intangible Taxable Goods and / or Taxable Services from outside Customs Area, no later than 15 (fifteen) months after the tax due. Article 2 paragraph (14) Value Added Tax and Sales Tax on Luxury Goods whose collection is carried out by the Treasurer of Expenditures as Value Added Tax Collection, must be deposited no later than 7 (seven) months after the Tax Period ends.

As for tariffs and taxes owed can not be separated from a sense of justice, because justice can create a social balance that is essential to the welfare of society. In determining the tax rate should be based on principles of justice, and also certainty. In the calculation of tax payable using tax rate.

Tax rate means the tariff to calculate the amount of tax payable (tax to be paid). If seeing the emergence of tax debts, that the tax debt arising from the Tax Decree, this doctrine applied to the official assessment system. Differences doctrine of material that the tax debt arose because legislation. This doctrine is applied to the self-assessment system.

The elimination of tax debt is caused by payment, the tax debt inherent in taxpayers will be removed because of payments made to the State Treasury. Compensation, the decision shown to tax debt compensation with a person's bill outside of tax is not permitted. Therefore 
compensation occurs if the Taxpayer has a bill in the form of excess tax payments. The amount of excess tax payments received by the previous taxpayer must be compensated with other taxes owed. Expiration interpreted as billing expired.

Rights to collect taxes expired after the expiry of ten years from the time of its outstanding tax or its ending tax period, part of the tax year or the relevant tax year. This is to provide legal certainty when taxes cannot be collected again. However, the tax collection date is deferred, among others, if a letter of reprimand and a letter of force are issued. Exemption, tax debt does not end up in the proper sense but because it abolished. Exemptions are generally not given to the tax principal, but are given to administrative sanctions. Elimination of the tax debt is the same nature as liberation, but given the taxpayer because of financial circumstances.

As previously stated in the Organization for Economic Co-operation and Development (OECD) there are 28 types of E-Commerce transactions online and potentially taxed one of which is Banner Advertising / Ads. Google Indonesia in this case conducts E-Commerce transactions online Advertising / Banner Ads. Google Indonesia is claimed to have avoided taxes by the Directorate General of Tax on Google Indonesia related to tax issues currently faced by Google Indonesia. The Directorate General of Tax will stage towards investigation because Google Indonesia refuses to be examined. Google Indonesia is considered to be avoiding taxes because it has not become a Permanent Business Entity in other words Google Indonesia has not become a Taxpayer.

So far, Google is only making a representative office in Indonesia is not a permanent office. Therefore, Google business transactions that occur in Indonesia have no effect on increasing state revenues. Even though transactions in Advertising / Banner Ads online conducted by Google in 2015 reached $\$ 850$ million (Eight hundred fifty million) or around Rp. 11,600,000,000.00 (Eleven trillion six hundred million rupiahs).

According to the Directorate General of Tax records, Google Indonesia has been registered as a domestic legal entity in the Tanah Abang III Tax Office with status as Foreign Investment (PMA) since 15 September 2011 and is a dependent agent from Google Asia Pacific Pte Ltd in Singapore. According to Article 2 paragraph (5) letter (n) of the Income Tax Law, Google should have the status of permanent so that any income originating from Indonesia has the right to be subject to income tax.

Countries of the Organization for Economic Co-operation and Development (OECD) have agreed that the collection of income tax on e-commerce transactions that have permanent establishments will use the principle source, if it does not have a permanent establishment will use the principle of domicile.

Explanation of Permanent Business Entity according to Article 2 paragraph (5) Income Tax Law, namely, Form of permanent business is a form of business that is used by individuals who do not reside in Indonesia, individuals in Indonesia no more than 183 (one hundred and eighty three) days within a period of 12 (twelve) months, and the agency is not established and domiciled in Indonesia for conducting business or conducting activities in Indonesia, which can be a place of management, branch companies, representative offices, office building, factory, workshop, warehouse, space for promotion and sales, mining and natural resource extraction, working area of the oil and gas, fisheries, animal husbandry, agriculture, plantation, or forestry, project construction, installation or assembly project, Provision of services in any form by employees or others, all made more than 60 (sixty) days within a period of 12 (twelve) months.

A person or entity acting as an agent whose position is not free, an agent or employee of an insurance company that is not established and not domiciled in Indonesia who receives 
insurance premiums or carries the risk in Indonesia, computers, electronic agents or automated equipment owned, rented, or used by the organizers of electronic transactions to conduct business over the internet.

\section{LEGAL CERTAINTY IN E-COMMERCE TAX REPORT}

Indonesia is a country of law (rechtstaat), these statements are listed in Article 1 Paragraph (3) of the Constitution of 1945. In the state of law, all of the policies set in a legislation. In the implementation of legal certainty, it is inseparable from law enforcement. It is necessary to have legal counseling to achieve a high level of legal awareness in the community so that people can live their rights and obligations in order to uphold the law, uphold justice, law order, legal certainty and attitude and behavior law-abiding.

The principle of legal certainty that the principle contained in the Case of Administration. If it is related to legal certainty in reporting taxes on previous E-Commerce transactions, the principle of legal certainty requires certainty, both for tax officers and all taxpayers and the entire community. The certainty principle includes certainty about the tax subject, tax object, tax base and the amount of tax rates and tax obligations compliance procedures.

The principle of certainty is divided into two, namely the legal certainty of material and legal certainty of formal. Legal certainty of material regulates the provisions regarding certainty about who is taxed, who is excluded, anything that is taxed and whatever is excluded and the amount of tax payable. Whereas legal certainty of formal regulates certainty regarding procedures for fulfilling tax rights and obligations as well as sanctions for those who violate tax obligations.

The principle of legal certainty also requires respect for the rights obtained by a person based on a decision by the state administration. The principle of legal certainty is the principle in a state of law that prioritizes the basis of legislation, propriety, and justice in every policy of the state administrator. The Directorate General of Tax conducts tax reforms that are in line with the dynamics of the economy and the business world in order to realize a fair, competitive tax system and provide legal certainty.

Taxpayer groups, generally, any taxpayer who has not fulfilled the obligation of Tax is allowed to participate in the Tax Amnesty program. This means that the Tax Amnesty program is intended for taxpayers who are already in the tax administration system. Different treatments possible when the taxpayer who want to participate in the Tax Amnesty program has been examined or is in the process of inspection. In this case, taxpayers who have been examined or are in the process of being audited are not allowed to participate in the Tax Amnesty program because the tax arrears are known by the tax authority.

Taxpayers also can be called clemency if the provisions of the legislation states that disclose taxpayer or wealth tax obligations voluntarily entitled to reduction or elimination of administrative sanction. Taxes and Tax Amount or administrative sanctions provided forgiveness, provisions of the Tax Amnesty should specify any given tax forgiveness. In general, tax incentives granted forgiveness come only from one kind of tax, such as Tax Amnesty is only given to the Personal Income Tax not included the Corporate Income Tax, or program Tax Amnesty solely devoted to the land and building tax only.

\section{CONCLUSION AND SUGGESTION}

Legal certainty in the tax bases of E-Commerce transactions associated with E-Filing, Tax Amnesty and Trading Through Electronic System can not be implemented effectively in Indonesia, because it does not have legal protection as a base and a clear goal in its 
implementation. Directorate General of Tax should be socialized in advance in order to Trading Through Electronic System can be implemented as well, with a lack of legal certainty it should be obvious to load whatever be the responsibility as an object and subject to tax.

Legal certainty in reporting taxes on electronic transactions can be carried out by providing clarity in the relevant legislation because of the impact of E-Commerce, which is growing rapidly every day. The government should be more alert again in making policy by tax amnesty which should not only remove Rights Bill on taxpayer but should improve tax compliance, so that in the long term can increase tax revenues, and of course it will be clear later on the responsibility of the subject and the object of Tax in provide tax reports.

\section{REFERENCES}

Achmad Ali, Menguak Tabir Hukum (Suatu Kajian Filosofis dan Sosiologis), Penerbit Toko Gunung Agung, Jakarta, 2002.

Achmad Tjahjono dan Muhammad Fakhri Husein, Perpajakan, Akademi Manajemen Perusahaan YKPN, Yogyakarta, 2005, ed. 3, cet.ke 1.

Ahmad Mujahid Ramli, Cyber Law dan HAKI Dalam Sistem Hukum Indonesia, Refika Aditama, Bandung 2004.

B. Usman dan K. Subroto, Pajak Indonesia, Gramedia Pustaka Utama, Jakarta, 1995.

Bohari, Pengantar Hukum Pajak, cet.6, PT. Raja Grafindo Persada, Jakarta, 2006.

Budi Sutedja. D.O, E-education konsep teknologi dan aplikasi internet pendidikan, C.V. Andi Offset, Yogyakarta, 2007.

C.F.G, Sunarjati Hartono, Politik Hukum Menuju Satu Sistem Hukum Nasional, Alumni, Bandung, 1991.

Dardji, Darmodiharjo Pokok-Pokok Filsafat Hukum, Apa dan Bagaimana Filsafat Hukum Indonesia, PT. Gramedia PustakaUtama, Jakarta, 2006.

Devano, Sony dan Siti Kurnia Rahayu, Perpajakan: konsep, teori dan isu, Kencana, Jakarta, 2006.

Diana Sari, Konsep Dasar Perpajakan, PT Refika Aditama, Bandung, 2013.

Djamaluddin Gede, Hukum Pajak, Lembaga Penerbit Fakultas Ekonomi Indonesia, Jakarta, 2002.

Djoko Slamet Surjoputro, Buku Panduan Hak dan Kewajiban Wajib Pajak, Direktorat Penyuluhan Pelayanan dan Humas, Jakarta, 2009.

Dominikus Rato, Filsafat Hukum Mencari: Memahami dan Memahami Hukum, Laksbang Pressindo, Yogyakarta, 2010.

Erly Suandy, Hukum Pajak (Dilengkapi dengan latihan soal), Salemba Empat, Jakarta, 2002. Elfis Wandi, Analisis Efisiensi dan Efektivitas Pemungutan Pajak Hiburan Mifan Terhadap Pendapatan Asli Daerah Kota Padang Panjang, Jurnal Akuntansi, www.upi.yptk.ac.id Padang, 2013.

Fahmi M. Ahmadi. Jaenal Arifin, Metode Penelitian Hukum, Lembaga Penelitian UIN Syarif Hidayatullah, Jakarta, 2010.

Fathul Wahid, Kamus Istilah Teknologi Informasi, C.V. Andi Offset, Yogyakarta, 2002.

Gustian Djuanda Irwansyah Lubis, Pelaporan Pajak Pertambahan Nilai Dan Pajak

Penjualan Atas Barang Mewah, PT Gramedia Pustaka Utama, Jakarta, 2011.

Hanny Kamarga, Belajar Sejarah Melalui E-Learning: Alternatif mengakses sumber informasi kesejarahan, Inti Media, Jakarta, 2002.

Haula Rosdiana, dan Rasin Tarigan, Perpajakan: Teori dan Aplikasi, PT. Raja Grafindo Persada, Jakarta, 2005.

dan Edi Slamer Irianto, Pengantar Ilmu Pajak: Kebijakan dan Implementasi 
di Indonesia, PT. Raja Grafindo Persada, Jakarta, 2012.

Herry Purnomo dan Theo Zacharias, Pengenalan Informasi Perspektif Teknis dan Lingkungan, CV. Andi Offset, Yogyakarta, 2004.

Laudin Marsuni, Hukum dan Kebijakan Perpajakan di Indonesia, UII Press, Yogyakarta, 2006.

Lia Sautunnida, Jual Beli Melalui Internet, Sinar harapan, Bandung, 2008.

Lili Rasyidi \& Ira Rasyidi, Dasar-Dasar Filsafat dan Teori Hukum, Citra Aditya Bakti, Bandung, 2001.

Lutfi Effendi, Pokok-Pokok Hukum Administrasi, Bayumedia Publishing, Malang, 2004. Mansury R, Kebijakan Perpajakan, YP4, Jakarta, 2000.

.............., Pajak Penghasilan Lanjutan Pasca Reformasi 2000, YP4, Jakarta, 2005.

Mardiasmo, Otonomi dan Manajemen Keuangan Daerah, ANDI, Yogyakarta, 2002. Perpajakan Edisi Revisi 2011, Andi Jogjakarta, Jogjakarta, 2011.

Mariam Darus Badrulzaman, Aneka Hukum Bisnis, Alumni, Bandung 1994.

Melwin Syafrizal, Pengantar Jaringan Komputer, C.V. Andi Offset, Yogyakarta, 2005.

Muhammad Djafar Saidi, Pembaruan Hukum Pajak, PT.Raja Grafindo Persada, Jakarta, 2007.

Mulyo Agung, Perpajakan Indonesia Seri PPN dan PPnBM Teori Aplikasi Edisi Revisi Cetakan Pertama, Dinamika Ilmu, Jakarta, 2007.

Muqodim, Perpajakan Buku Satu, UII Press, Yogyakarta, 1999.

Moctar Kusumaatmadja, Pembinaan Hukum Dalam Pembangunan Nasional, Bina Cipta Bandung, 1982.

Moleong J. Lexy, Metode Penelitian Kualitatif, PT. Remaja Roda Karya, Bandung 2004.

Nufransa Wira Sakti, Buku Pintar Pajak E-Commerce, Visimedia, Jakarta, 2014.

Onno W. Purbo dan Aang Arif Wahyudi, Mengenal e-Commerce, Elex Media Komputindo, Jakarta, 2001.

P. J. A. Andriani, Pajak dan Pembangunan, UI Press, Jakarta, 2000.

Panggih P. Dwi Atmojo, Internet Untuk Bisnis I, Dirkomnet Training, Jogjakarta, 2002.

Peter Mahmud Marzuki, Pengantar Ilmu Hukum, Kencana, Jakarta, 2008.

R. Santoso Brotodihardjo, Pengantar Ilmu Hukum Pajak, Eresco, Bandung.

Riduan Syahrani, Rangkuman Intisari Ilmu Hukum, Penerbit Citra Aditya Bakti,Bandung, 1999.

Rachmat Soemitro, Pengantar Singkat Hukum Pajak, Eresco, Bandung, 1987.

Ronny Hanitjo Soemitro, Metodologi Penelitian Hukum dan Jurimetri, Ghalia Indonesia, Jakarta, 1990.

Safri Nurmantu, Pengantar perpajakan, edisi 2, Granita, Jakarta, 2003.

SF Marbun Moh Mahfud MD, Pokok-Pokok Hukum Administrasi Negara, Liberty, 2006.

Siti Resmi, Perpajakan Teori dan Kasus, Buku I, Salemba Empat, Jakarta, 2003.

Soerjono Soekanto, Pengantar Penelitian Hukum, UI Press, Jakarta, 1986.

Mariam Darus Badrulzaman, Sutan Remy Sjahdeini, Heru Soepraptomo, Faturrahman Djamil, dan Taryana Soenandar, Kompilasi Hukum Perikatan, Citra Aditya Bakti, Jakarta, 2001.

Y. Sri Pudyatmoko, Pengantar Hukum Pajak, Lembaga Penerbit Andi, Yogyakarta, 2009.

Waluyo, Perpajakan Indonesia, Edisi 10 Buku 1, Salemba Empat, Jakarta, 2011. 